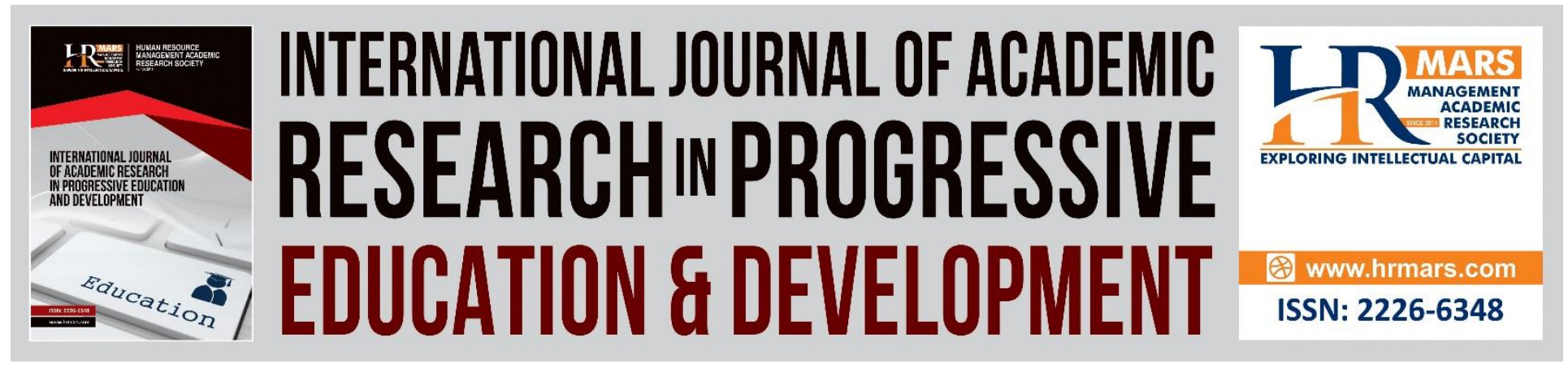

\title{
The Pathways to Student Leadership and Effects of Training on Students' Leadership Competence
}

Alfred Kuranchie, Prince Kwame Affum

To Link this Article: http://dx.doi.org/10.6007/IJARPED/v10-i1/8329

DOI:10.6007/IJARPED/v10-i1/8329

Received: 23 December 2020, Revised: 20 January 2021, Accepted: 10 Febuary 2021

Published Online: 26 February 2021

In-Text Citation: (Kuranchie \& Affum, 2021)

To Cite this Article: Kuranchie, A., \& Affum, P. K. (2021). The Pathways to Student Leadership and Effects of Training on Students' Leadership Competence. International Journal of Academic Research in Progressive

Education and Development, 10(1), 114-129.

Copyright: (C) 2021 The Author(s)

Published by Human Resource Management Academic Research Society (www.hrmars.com)

This article is published under the Creative Commons Attribution (CC BY 4.0) license. Anyone may reproduce, distribute, translate and create derivative works of this article (for both commercial and non-commercial purposes), subject to full attribution to the original publication and authors. The full terms of this license may be seen at: http://creativecommons.org/licences/by/4.0/legalcode

Vol. 10(1) 2021, Pg. 114 - 129

http://hrmars.com/index.php/pages/detail/IJARPED

JOURNAL HOMEPAGE

Full Terms \& Conditions of access and use can be found at http://hrmars.com/index.php/pages/detail/publication-ethics 


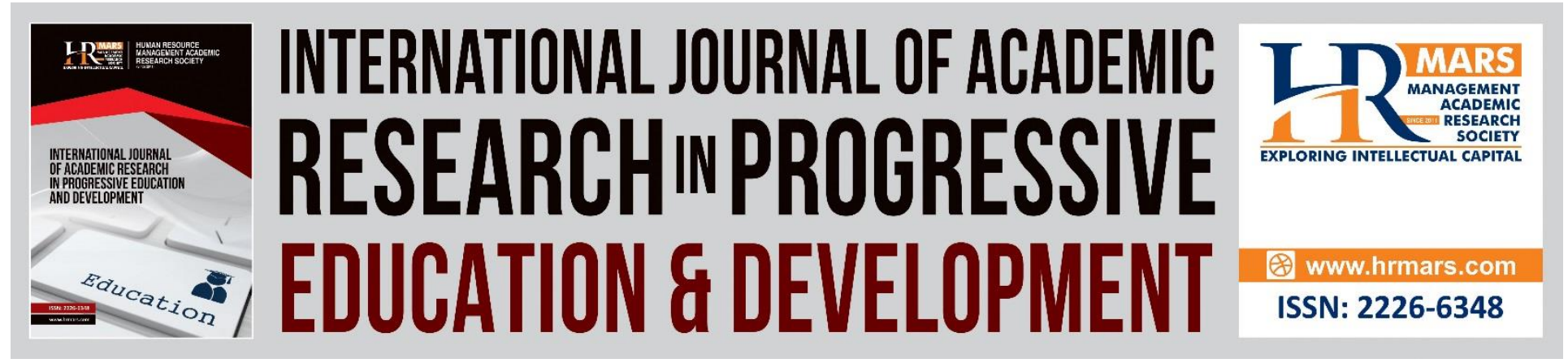

\title{
The Pathways to Student Leadership and Effects of Training on Students' Leadership Competence
}

\author{
Alfred Kuranchie, (Ph.D) \\ Department of Social Studies Education, University of Education, Winneba, Ghana. \\ Email: kuranchiealf@yahoo.com \\ Prince Kwame Affum, (PhD Candidate) \\ Counselling Unit, University of Energy and Natural Resources, Sunyani. Ghana. \\ Email: prince.affum@uenr.edu.gh
}

\begin{abstract}
In democratic dispensations, student leadership is reckoned to be an essential means of preparing students for the macro society. In the post-industrial era, all levels of education have been encouraging student leadership as a means of involving students in school governance. Consequently, this study set out to unravel the similitude and semblance of democratic ideals and values in choosing student leadership in senior high schools and the effect of student leadership training. The study utilised new prefects who were attending leadership training prior to assumption of duty. Descriptive and experimental designs were employed to execute the study to achieve the set goals. The study revealed that the schools adopted democratic means of getting most of their prefects as prospective leaders went through electoral processes by picking up nomination forms, going through vetting, canvasing for votes, going through balloting and receiving induction prior to assumption of office. It also emerged that the training had significant effects on students' knowledge on leadership. As the training proved to be quintessential in positioning students for their leadership functions, the schools need to continue with the practice and those which do not do same for their prefects ought to wake up from their slumber and do the needful for the benefit of students, schools and the society.
\end{abstract}

Keywords: Student Leadership, School Prefects, High School, Motivators and Leadership Training

\section{Introduction}

All set ups make use of leadership to get things moving and in the right directions to achieve set goals. Northouse (2004) regards leadership is a process of influencing people to achieve common goal(s). It is the act of directing a group towards a desired end. Student leadership entails some students shepherding their colleagues to pursue common affairs and enhance their welfare. Student leadership has been recognised as vital in the running of schools 
and as a preparation of young people for the larger society. This brings about a shared leadership between head teachers, teachers and students in school (Awiti, 2009). Student leadership is one sure way to getting students actively involved in the running of a school. Educators need not only aid students to learn about people in leadership positions but also to develop their desire and capacity for leadership roles. It is also not sufficient to prepare students to follow but also to lead (O'Brien, \& Kohlmeier, 2003). This is because students 'learn about democracy', 'learn through democracy' and 'learn for democracy' (Ruddock \& Fielding, 2006).

Schools normally get prefects in the last term of an academic year to perform leadership role in the ensuing year. These prefects then constitute Student Council or Student Representative Council (SRC). Student council is a representative structure for students, through which they become involved in the management of affairs of the school work in concert with school management, staff and parents for the benefit of the school and its students (National Youth Council of Ireland, 2011). The council has a constitution, which guides its operations. It has been stressed that student councils need to have written constitutions, which should unambiguously stipulate the respective prefects' responsibilities to enable them perform their duties effectively (Kyungu, 2009). The constitution provides enough guides for students to work within the remit of the law.

\section{Relevance of Student Leadership}

Student leadership has a litany of relevance as whatever prefects participate in tends to be beneficial to the student, school and the society (Obiero, 2012). When students participate in school governance, they acquire democratic culture and attitude, develop good attitude to work, develop a sense of belongingness to both school and society as well as learn to be self-directing, responsible and law-abiding. Student leadership has the propensity to promote youth involvement in the affairs of their institutions. Students' involvement in decision making in school also tends to promote teacher-student relationship, make students feel belonging, and create congenial environment for learning (Kyei-Badu, 2010) and it also prepares students to acquire socio-moral competencies [9]. Young people need to have freedom of expression and appropriate participation in policy making as enshrined in the United Nations Convention of the child. Children have the right to be heard on issues that affect them (Kiruthu, 2011).

Leadership experience contributes to students' development (Myers, 2005). If educational institutions permit student involvement in school governance, both leaders and followers gain a lot. Student leadership introduces students to democratic ideals and practices that they need in the society: as school is a microcosm of society. The entire students in the school learn and practise democratic values, ideals and processes that await them in the larger society. The prefects, in particular, learn those democratic ideals and values, and play leadership roles as well, which all contribute to improving their competence for their future social and work life. In effect, leadership prepares students to be democratic citizens.

If schools are democratised, teaching of responsibility to self and others can boost leadership in schools and beyond (Njogu, 2004) A similar view has been expressed to the effect that reforms become successful if students participate in their enunciation and implementation (Levin, 2000). Students' involvement makes them own the policies and work assiduously toward 
their achievement. Students also become more positively predisposed towards school goals and objectives when governance is shared (Obondo, 2000).

The psychological benefits of student leadership are that this opportunity helps students to gain self-concept, self-confidence and develop divergent thinking skills as they participate in high level decision making. These virtues contribute to their human capital, which may help in societal development after school. Ceteris peribus, both student leaders and non-student leaders transfer these virtues to the groups, communities and organisations in the society that they would find themselves and work with.

\section{Modes of Choosing Student Leaders}

The two major means through which student leaders emerge in educational institutions are by appointment and election. In other words, student leaders are either appointed by school authorities or elected by the study body. By appointment, heads of schools and/or teachers choose students they consider suitable and fit for purpose to lead the student body. In this case, opportunity is not extended to the entire students to determine the suitability or otherwise of the appointed leaders. It has been observed that there are many schools which allow teachers to choose student leaders with little or no input from the student body (Otieno, 2001). With the latter means of getting student leaders, however, democratic processes are scrupulously followed in electing prefects. Every student then is offered the chance and opportunity to vote and be voted for. Student leader hopefuls go through democratic means such as picking of nomination forms, vetting, reading of manifesto, campaigning and canvassing for votes, and balloting to ascertain the suitability and qualification of the aspirants. In this mode, there is assurance of free, fair and transparent process of choosing prefects. Students tend to acquire democratic virtues, culture, integrity and accountability as they go through democratic processes of choosing their leaders, which later can be beneficial to them, their schools and the society.

Democratic means of choosing student leaders seems to have gained currency and popular acceptance in educational institutions in democratised societies. The institutions put in place arrangements to ensure successful election of school prefects. For instance, in Zimbabwe, and for the avoidance of doubt, the Ministry of Education has produced guidelines on choosing student leaders. In their schools, students have the mandate to choose their leaders and where the head teachers wield the power to veto the appointments, prefects need to be academically above average (Wachira, 2004). Ostensibly, academically weak students' performance will be exacerbated if they have to combine studies with prefectship responsibilities; so, they do not have to be appointed as leaders in school. With the guidelines, school authorities and teachers do not have the power to arbitrarily impose leaders or prefects on students.

\section{Roles of Student Leaders}

In school, both authorities and members of the School Representative Council (SRC) need to be clear on the roles of the latter (Dowling, 2003). SRCs perform representational, supervisory, guidance and counselling and other roles. On the representational role, a well constituted student council represents students' interests in the schools that account for their representation on various committees. Prefects present issues that boarder students to authorities, assist to create a congenial learning atmosphere and aid to reduce students' unrests (Chemutai \& 
Chumba, 2014). The prefects serve as a link between students and administration, promote communication between the two parties, serve as voice of the students, seek the welfare of students, send students' views on developments and activities in the school, grievances and suggestions to the attention of school authorities, help promote peaceful school environment and help school administration to thrive and succeed.

For the supervisory role, the prefects ensure that students perform their duties; behave themselves in class, libraries and laboratories; assist in organising sports and games and ensure students participate in them; ensure that students adhere to rules and regulations; and ensure that sanity prevails at all times at preps, dining and other places of interest to school administration. Students' participation in supervisory roles helps them to develop leadership skills, which they need in both their social and work settings (Okumbe, 2001).

With regard to counselling and disciplinary role, prefects are expected to counsel; provide support, encouragement and advice to students and when the need arises, report offences to appropriate officers. As part of their counselling responsibilities, prefects help to resolve conflicts and deal with minor discipline cases at the grassroot. Other roles of SRC at the senior high school are promoting the values of the schools, undertaking projects and organising social events to enhance the life of students in school.

\section{Training of Student Leaders}

Training is deemed to be a good means to expose student leaders to their responsibilities. Student leaders ought to be equipped with the competencies prior to assumption of office. It is an incontrovertible and uncontestable fact that when duties are assigned to prefects without appropriate training and guidance, they may be confused, disorganised, tensed and downhearted, which may result in abysmal performance. For student leaders to exquisitely perform their responsibilities to be exceptional, they need to be trained, guided by instructions and rules of work and there should be clearly stated tasks they would perform (Kyungu, 2009).

Training enables student leaders to be abreast of their roles and responsibilities. It also helps them to know their limits. It is highly relevant for school authorities to expose prefects to their functions and scope within which they would operate (Okumbe, 2009). Furthermore, training of prefects helps them to efficiently lead students from diverse socio-cultural and economic backgrounds. Ghana's senior high school admission system (the Computerized School Selection and Placement System-CSSPS), for instance, encourages students to move to any geographical environment to pursue high education hence student leaders ought to be equipped with the competence to provide good leadership for all.

Besides initial training, prefects could be given continuous training via workshops, seminars, symposia and conferences to refresh their minds, and update and upgrade their knowledge and skills in leadership. Areas that student leaders need training are leadership and leadership styles, qualities of good leaders, and duties and responsibilities of student leaders.

To know the efficacy of training, different types of evaluation are carried out. The three main types of evaluating training programmes are process, outcome and impact evaluations (Kuranchie, 2019). Process evaluation is the constant monitoring of training activities while in progress to identify deviations for correction whereas outcome evaluation is the finding out of the effectiveness of training activities immediately after the programme. The impact evaluation, 
on the other hand, is ascertaining the direct and indirect impacts of the programme after some time (Kuranchie, 2019; Beardwell, Holden \& Claydon, 2004). Impact evaluation answers the question "how much of the training has been retained and used by the trainees at their work places after a period of time (Mncbe, 2008).

\section{Prior Research Efforts}

It is believed that students, as a major stakeholder in school, need to play vital and critical roles in decision making in their schools (Mukiri, 2014). A survey of literature revealed that in the contemporary times, all levels of education embrace student participation in school governance. Consequently, extant literature is replete with empirical studies that have been conducted on various aspects of student leadership such as roles of student council in management of school (Mukiri, 2014; Kinyua, 2015), factors influencing effectiveness of school council (Tshabangu, 2006), extent of student leader participation in decision making (Cockburn, 2006; Mule \& Sahin, 2005), students' perspectives on student participation in decision making (Kyei-Badu, 2010, Ankomah \& Pepra-Mensah, 2006; Rudduck \& Fielding, 2006; Hine, 2014), student leadership programmes in schools, leadership training needs of prefects and role of prefects in enhancing discipline (Mukiri, 2014). In spite of the plethora of the studies executed on student leadership, significant gaps exist in research on 'the processes leading to choosing student leaders', 'the factors that induce students to opt for leadership positions', 'the means of choosing student leaders', 'the preparation given to student leaders for their leadership roles' and 'the impact of leadership training on student leaders' leadership competence'. This research, therefore, was fashioned to address these non-researched issues to broaden understanding on student leadership.

\section{Research Questions}

The study sought answers for the following questions, which emerged from the literature review:

- Which programme(s) dominate in the student leadership of the schools?

- What is the mode of choosing student leaders in the schools?

- What motivate student leaders to opt for leadership positions in the schools?

- What is the impact of training on student leaders' knowledge on leadership functions?

\section{Theoretical Framework}

The study is hinged on the social systems theory, which is the interdisciplinary approach in examining systems in general. A school is an active and a vibrant social system, which consists of head teachers, teachers, ancillary staff, students and other stakeholders who perform diverse roles in achieving the desired learning outcomes. These sub-units in the school system work coherently and collaboratively to achieve set goals. In the performance of their roles, the subunits depend on each other to achieve the common goals. The social systems theory reiterates the need for the sub-units to work in a more co-ordinated and coherent manner for the entire school system to accomplish its goals.

Leadership as a system concerns with components connected and interconnected, whose job is oriented towards the goal (Ramosai \& Berisha, 2014). Student leadership as a constituent of the school system needs to be recognised, appreciated, permitted and supported to execute 
Vol. 10, No. 1, 2021, E-ISSN: 2226-6348 @ 2021 HRMARS

its roles. If student leadership is highly embraced in senior high schools, authorities would adopt democratic means of getting qualified and competent students and also offer them appropriate training to adequately prepare them for their responsibilities. This standpoint underscores the use of the systems theory in this research.

\section{Conceptual Framework}

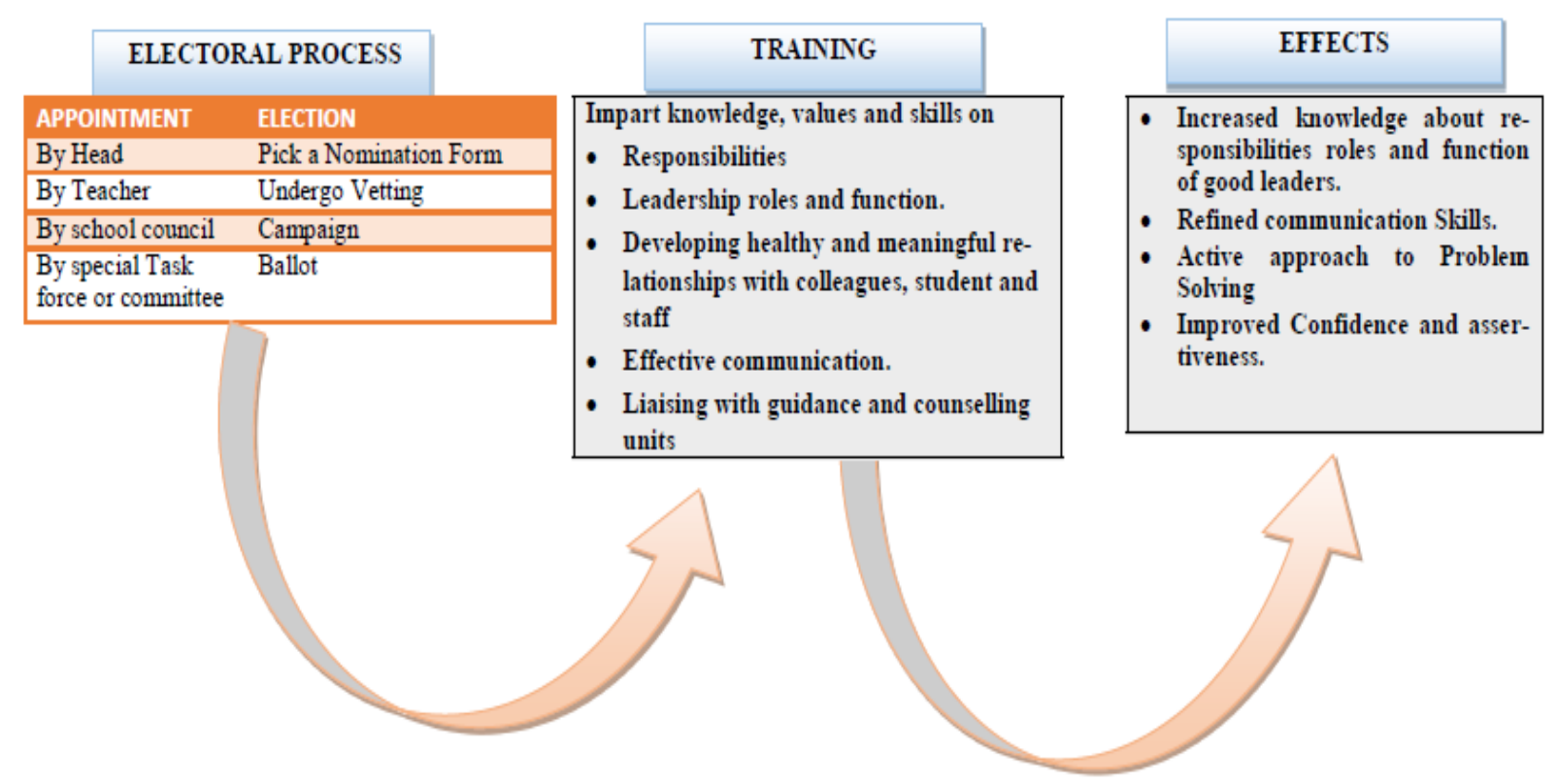

Figure 1: Conceptual framework of processes involved in selecting student leaders, training and its effects

Authors' construct

Student leaders emerge from either appointment or election, which offers them authority to lead. Sequel to their selection, student leaders receive induction and other forms of training to acclimatise and fortify them with their roles and responsibilities. Effective training and education offered to new prefects would culminate in making them to acquire the functional prerequisite competencies to lead effectively and efficiently.

\section{Methods and Materials}

\section{Study Designs}

The study relied on the descriptive survey and experimental designs to ascertain processes which lead to choosing student leaders in the schools and the impact of leadership training on student leaders respectively. The first phase of the study required administration of questionnaire to gather data on the processes leading to selection of student leaders in the schools, and motivation for opting for leadership positions. The second phase, on the other hand, was an experimental study, which was conducted to assess the impact of training on prefects' knowledge on student leadership. This attempt utilised one-group pre-test-post-test preexperimental design, involving implementation of pre-test, intervention and post-test with no 
Vol. 10, No. 1, 2021, E-ISSN: 2226-6348 @ 2021 HRMARS

control group (Kuranchie, 2016). The two designs aided greatly in generating quantitative data for analysis to achieve the rationales of the study.

\section{Study Population}

Captive audience of prefects who were undergoing leadership training constituted the study population. A total of 226 newly elected prefects from 12 Catholic senior high schools in the Brong Ahafo region of Ghana who participated in a one-day intensive leadership training exercise were used for the study. For the last three years, the Association of Catholic Heads of Higher Institutions has been organising training for new prefects of their schools. The prefects included head prefects, chaplains, compound overseers, health and hygiene officers, protocol, dining hall, library, preps, sports, entertainment, house prefects and their assistants.

In the schools, as in all other senior high schools in Ghana, the tenure for all prefects is for an academic year. Student leaders are chosen at the tail end of the third term of the second year to hold office in the ensuing academic year. Effectively, their reign is in the third year of their senior high education. It is worthy to note that the schools do not use previous leadership experience as an eligibility criterion for election into leadership position. This situation permits first time aspirants also to vie and compete for positions they consider themselves fit. This in turn makes leadership training for prefects a sine qua non and inevitable to prepare the novice leaders for a smooth take off and exquisite execution of their functions.

\section{Data Collection Methods}

The two sets of tools which were developed and used to gather the data for the study are questionnaire and achievement test. One, a semi-structured questionnaire was developed and administered to elicit data from the study subjects. The instrument solicited data on some demographic characteristics, mode of selection, previous leadership experience and motivation for opting to lead. Prior to its administration, the questionnaire was pre-tested and the reliability co-efficient of 0.78 , which is higher than 0.50 was found. On the basis of the high reliability, the instrument was considered worthy of administration to gather data for the main study.

Two, a non-standardized achievement test was developed and conducted as pre-test and post-test to assess the effect of the leadership training. The pre-test was conducted to gauge the prefects' knowledge on the issues in the intervention (presentation which covered leadership, student leadership, qualities of a leader, duties and responsibilities of student leaders, challenges and how to navigate them). The pre-test was set in order to determine the prefects' knowledge on these pertinent leadership issues. The prefects answered the questions prior to the conduct of the training. The items on the instrument covered all the three sections of the issues that were to be taught during the training. Item analysis and reliability co-efficient calculation were done prior to the conduct of the pre-test. KR-20 analysis was used for the reliability of the test. The reliability co-efficient was $r=0.81$, which is higher than 0.50 . The questions were marked over 50 .

The intervention or training had three sessions: Session ' $A$ ' - covered definition of leadership, student leadership, leadership styles and qualities of a leader; Session ' $B$ ' - treated roles and responsibilities of student leaders; and Session ' $C$ ' - covered challenges of student leadership and way forward. The training was facilitated by the authors of this paper. 
Post-test was done as an outcome evaluation to measure knowledge gained from the training. Essentially, the post-test data was used to gauge effectiveness of the training programme. To achieve this intention, the pre-test was administered as post-test to gauge the knowledge gained from the training. Consequently, pre-test and post-test scores were used for the analysis.

\section{Data Processing and Management}

Statistical Product for Service Solution (SPSS) version 22 was used to analyse both the survey and experiment data after they have been screened, edited and coded. While descriptive statistics was used to analyse the survey data, inferential statistics (paired samples t-test) was used to check the effect of the training on prefects' knowledge on student leaders' functions.

\section{Results of the Study}

The results of the data analysis are presented in two parts. The first part presents the outcomes of the survey while the second part covers the outcome of the experiment.

\section{Part One: Outcomes of the Survey}

Results of data analysis of personal data of respondents and the variables of the study are presented in this part of the write up. Table 1 presents the personal information on the respondents.

Table 1: Personal Information on Respondents

\begin{tabular}{l|c|c}
\hline & Frequency & Percent (\%) \\
\hline Sex & & \\
Male & 84 & 37.2 \\
Female & 142 & 62.8 \\
Total & $\mathbf{2 2 6}$ & $\mathbf{1 0 0}$ \\
Age bracket & & \\
$<15$ years & 5 & 2.2 \\
$16-18$ years & 193 & 85.4 \\
$>18$ years & 28 & 12.4 \\
Total & $\mathbf{2 2 6}$ & 100 \\
Programme of Study & & \\
General Arts & 68 & 30.1 \\
Visual Arts & 32 & 14.2 \\
Vocational Skills & 17 & 7.5 \\
Business & 56 & 24.8 \\
Elective Science & 38 & 16.8 \\
Agricultural Science & 15 & 6.6 \\
Total & $\mathbf{2 2 6}$ & $\mathbf{1 0 0}$ \\
\hline
\end{tabular}

The data analysis portrays that the female prefects outnumbered the males. The male prefects were 84 representing $37.2 \%$ while the female prefects were 142 representing $62.8 \%$. The female higher representation in the school prefect councils of the Catholic senior high 
schools in the region is as a result of the high number of single sex female schools as opposed to the only single sex male school in the region. The rest of the schools are mixed sex schools.

The results in Table 1 depict that the prefects were in the normal school age. This is because a colossal number of 193 prefects representing $85.4 \%$ were between 15 and 18 years. As has been alluded to earlier, students who commence their formal school at the normal school age of 6 should complete senior high school at age 18. The results reveal that only 5 prefects representing $2.2 \%$ were less than 15 years at the time of the training programme, meaning they might have started formal education very early and 28 prefects representing $12.4 \%$ were above 18 years, implying that they might have started formal education late or certain factors might have affected their completion of the basic school.

The results in Table 1 further disclose that more prefects were pursuing General Arts (68, $30.1 \%)$ and Business $(56,24.8 \%)$ programmes while the Vocational Skills $(17,7.5 \%)$ and Agricultural Science $(15,6.6 \%)$ programmes had less representation in the prefectship positions in the schools. It is plausible that some topics on management, leadership, decision making, politics and others in some General Arts and Business subjects might have influenced more students in these disciplines to opt for leadership positions in the schools as opposed to those in the sciences.

The research was also interested in unveiling the mode of and processes entailed in selecting leaders in the schools. Table 2 displays results on how the prefects were selected in the schools.

Table 2: Mode of choosing prefects

\begin{tabular}{lcc}
\hline Mode & Frequency & Percent (\%) \\
\hline Appointment & 38 & 16.8 \\
Election & 188 & 83.2 \\
\hline Total & $\mathbf{2 2 6}$ & $\mathbf{1 0 0}$ \\
\hline
\end{tabular}

The results presented in Table 2 disclose that a disproportionate chunk of the prefects was democratically elected by the student body. However, less than a quarter of them indicated that they were appointed by the school authorities. These prefects elucidated that in the schools, some prefects such as chaplain, health and protocol positions are not elective. They explain further that such prefects are chosen by school authorities with inputs from staff in-charge of the units. They added that such positions need students with some expertise, attitude, character and dispositions which befit the office, hence, they are not elective positions in the schools.

As two prefects wrote,

if you allow students to elect a student chaplain, they may elect someone they know very well do not wield the religious and spiritual giftedness for the work and cannot help in that course.

Suggestively, school administration believes that the general student body did not possess the well-withal to identify and choose such qualified students to hold the specialised offices should they be allowed to go through electoral processes. For instance, a chaplain of a school is permitted to choose a student who, in his or her view, possesses proven qualities, virtue and tenacity of purpose for the religious office. 
Vol. 10, No. 1, 2021, E-ISSN: 2226-6348 @ 2021 HRMARS

It also emerged from the survey that all the schools observe the democratic processes of electing leaders. The prefects outlined the following as the processes leading to their election into office:

giving notice of poll; invitation of nominations; vetting; campaigning including reading of manifestos; casting and counting of votes (in the presence of the candidates or their representatives); and declaration of results.

The prefects reiterated that the electoral processes are handled by electoral commissions, made up of selected teachers. The school authorities set up and mandate the electoral commissions to execute this civic responsibility in the schools.

A vital issue in the leadership discourse is eligibility. Undoubtedly, different eligibility criteria are used for leadership positions in various circles. The study, therefore, deemed it expedient to unearth what the schools set in place as eligibility criteria for student leadership. The results show that the schools seemed to have the same requirements for all student leaders. The consensus was that student leader hopefuls needed to be in the second year, in good academic standing and have good character.

An attempt was also made to verify if religious background and previous leadership experience were some of the eligibility criteria for leadership positions in the schools. Surprisingly but commendably, there was a $100 \%$ consensus among the respondents that the Catholic senior high schools do not use religious affinity as a basis for selecting student leaders. Some of the prefects indicated that although they were in Catholic institutions they belonged to different faiths or religious denominations. This development insinuates that the school authorities did not discriminate in the membership of student leadership.

The results on the quantum of prefects who had held leadership position at the basic school level are presented in Table 3. This attempt was made to ascertain the influence of prior experience in leadership on opting for leadership position at the senior high school.

\section{Table 3: Previous Leadership Experience}

\begin{tabular}{lcc}
\hline & Frequency & Percent (\%) \\
\hline Yes & 91 & 40.3 \\
No & 135 & 59.7 \\
\hline Total & $\mathbf{2 2 6}$ & $\mathbf{1 0 0}$ \\
\hline
\end{tabular}

The result shows that the prefects with prior student leadership experience are way less than those without it. Whereas barely $40 \%$ of the prefects have had leadership experience at the basic level of education, almost $60 \%$ of them did not have the experience of leading students. This finding drums home the idea that leadership training was essential for them. As found in a study, senior high student-leaders need training to be prolific on their prefectship responsibilities (Kikuvi, 2004). As students in their mid-adolescence and without leadership experience, leadership training was a sure way to prepare them for the onerous responsibilities associated with the positions that they had been given.

Lastly, the prefects were requested to indicate their motivation to vie for leadership positions in the schools. The following were the overriding ones:

the vision and ambition to hold leadership position in future;

the desire to lead and utilise leadership skills; 
possession of the competence to lead others;

having the interest and passion to lead;

the desire to contribute to the maintenance of discipline and

general growth of the school;

inspirations from others such as teachers, parents and colleagues; and

inspirations from previous leaders.

\section{Part Two: Outcome of the Experiment}

The results of the experimental are presented in Tables 4 and 5.

Table 4: Paired Samples t-test

\begin{tabular}{|c|c|c|c|c|c|c|c|c|c|}
\hline & & Paire & Difference & & & & & & \\
\hline & & & Std. & Std. & $\begin{array}{l}95 \% \\
\text { Confid } \\
\text { interva } \\
\text { differe }\end{array}$ & $\begin{array}{l}\text { nce } \\
\text { of the } \\
\text { ce }\end{array}$ & & & Sig.(2- \\
\hline & & Mean & Deviation & $\begin{array}{l}\text { Error } \\
\text { Mean }\end{array}$ & Lower & Upper & $\mathrm{t}$ & $d f$ & tailed) \\
\hline $\begin{array}{l}\text { Pair } \\
1\end{array}$ & $\begin{array}{l}\text { Knowledge on } \\
\text { leadership } \\
\text { responsibilities - } \\
\text { Time } 1 \\
\text { Knowledge on } \\
\text { leadership } \\
\text { responsibilities - } \\
\text { Time } 2\end{array}$ & 16.6 & 5.83 & .39 & 15.88 & 32.48 & 42.83 & 225 & .000 \\
\hline
\end{tabular}

Table 5: Paired Samples Statistics

\begin{tabular}{llllll}
\hline & Mean & N & Std. Dev. & Std. Error Mean \\
\hline Pair 1 & $\begin{array}{l}\text { Knowledge on leadership } \\
\text { responsibilities etc } \\
\text { before the training - }\end{array}$ & 20.1903 & 226 & 4.92920 & .32789 \\
& $\begin{array}{l}\text { Time 1 } \\
\text { Knowledge on leadership } \\
\text { responsibilities etc after } \\
\text { the training - Time 2 }\end{array}$ & 36.7920 & 226 & 6.96570 & .46335 \\
\hline
\end{tabular}

The paired samples t-test was conducted to assess the impact of training on prefects' knowledge on student leaders' responsibilities. The data analysis yielded results, which demonstrate significant increase in the prefects' knowledge on student leaders' responsibilities scores from Time $1(M=20.19, S D=4.93)$ to Time $2(M=36.79, S D=6.97), t(225)=42.83, p<.0005$ (2tailed).

The mean increase in knowledge on student leaders' responsibilities was 16.6 with a 95\% confidence interval stretching from 15.88 to 32.48 . The results imply that there was a significant 
difference in the prefects' knowledge on leadership, qualities of a good leader, functions of student leaders and challenges inherent in student leadership prior to and after their participation in the training programme.

\section{Conclusion}

The processes leading to having effective student leaders to help in school governance are noteworthy. The research unveils that students pursuing General Arts and Business programmes dominate in the student leadership in the Catholic senior high schools in the Brong Ahafo region, Ghana. It also emerged from the survey that the senior high schools observed the processes and values inherent in democracy, which is a good pathway of choosing and preparing students for democratised societies. It is believed that via the processes, students would learn and acquire knowledge and skills critically needed in contemporary homes, workplaces and societies. If students go through these processes in every year for the three years they spend in the senior high school, they would amass commendable democratic virtues and ideals required to be good citizens. For the student leaders, they would, in addition, get the experience of leading, which add more feathers in their cups. The research also disclosed that the students' motivation and confidence in their leadership competence as well as their desire to contribute to the growth and development of the schools triggered them to vie for the respective positions in the schools.

Lastly, the research disclosed the potency of training in improving prefects' knowledge and skills in leadership. The results of the experiment convincingly demonstrate that the training significantly improved the leadership capacity of the prefects. The enhanced leadership capacity of the prefects would enable them to provide meaningful leadership during their tenure in their respective schools. It is further hoped that the training has empowered and emboldened the prefects to superbly and skillfully execute their prefectship roles. It is also expected that the schools' authorities would recognise the value in student leadership training and sustain the practice by organising it, every year, for their new student leaders. Notwithstanding the positive influence of training on the prefects' knowledge, impact evaluation needs to be carried out to discover the evidences of the long-term impacts of the training. The outcomes of impact evaluation would let organisers and heads of schools know how far the training had affected the prefects' leadership skills and responsibilities. It is a sure way to ascertaining the extent to which the prefects have applied the knowledge and skills acquired from the training. This kind of evaluation can also guide the direction of future training programmes to provide more meaningful training for student leaders. Data from impact evaluation needs to come from multiple sources including the prefects and their peers, teachers and heads of school for triangulation purposes to improve credibility and trustworthiness of the results which would emerge from the study.

\section{Contributions of the Research}

The contributions that this study makes to knowledge and practice cannot be discounted. Firstly, the study provides responses to questions that begged for answers in literature. The findings of the study add to the stock of literature and broaden understanding on student leadership at the high school echelon of the educational system. 
Secondly, an outcome of the study disclosed that training has significant impact on student leaders' knowledge on the job that waits them. This positive outcome of leadership training would inform school authorities of the relevance of training prefects towards their leadership roles and responsibilities.

Thirdly, the outcomes of the study have the potency to stimulate further systematic inquiry into student leadership for validation. The study also emphasizes the need for impact assessment to ascertain long time effects of training programmes for student leaders. This kind of evaluation is not usually done by facilitators and organisers of training programmes, which denies stakeholders of knowledge on how efficaciously and effectively that trainees apply competencies gained in the real situations.

\section{Limitations and Suggestions for Further Research}

There are some challenges that confronted the study, which demand caution in judging the results. In the first place, the study was conducted in only faith-based schools, which share the same management ideals, among others. Non faith-based schools did not participate in the study to know how senior high schools in the jurisdiction handle student leadership issues. There is, therefore, lack of representativeness in senior high schools in the study.

Again, the study employed only quantitative approach and data gathering methods as guide to the study. This modus operandi did not warrant generation of unanticipated responses to add more flesh to the bones. Open-ended approach would have yielded some additional data to enrich the outcomes of the study.

Lastly, data was gathered from only prefects, without inputs from teachers and heads of schools who are also involved in the processes leading to student leadership. This presents a onesided view of the phenomena studied. Inputs from the school authorities and documentary sources such as report cards to unveil prefects' performance and behaviour would have added more credence to the results.

These pitfalls require the following efforts. One, the study should be replicated in other faith-based and non-religious senior high schools to ascertain the situation over there. The results of the study can, therefore, be compared to determine similarities and dissimilarities in student leadership practices and processes in the various kinds of senior high schools in the jurisdiction. Two, future research needs to adopt the mixed methods approach to generate both anticipated and unanticipated data, which would provide comprehensive information on student leadership at the high school level of education. Three, future research into the phenomenon studied should employ source triangulation to generate data from all major and active players in choosing of and working with student leaders at the high school level of education.

\section{Acknowledgement}

We appreciate the opportunity offered by the conference of heads of catholic higher institutions to facilitate the student leadership training they organised at sacred heart senior high school at nsuatre.

\section{References}

Ankomah, Y. A., \& Pepra-Mensah, J. (2006). Perspectives of student participation in 
INTERNATIONAL JOURNAL OF ACADEMIC RESEARCH IN PROGRESSIVE EDUCATION AND

DEVELOPMENT

Vol. 10, No. 1, 2021, E-ISSN: 2226-6348 @ 2021 HRMARS

decision-making in teacher training colleges. The Integrator, 1(1), 25-36.

Awiti, J. (2009). The principal magazine. Nairobi: UNESCO Publishers.

Beardwell, I., Holden, L., \& Claydon, T. (2004). Human resource management: Contemporary approach. ( $4^{\text {th }}$ ed.). London: Pearsons Inc.

Chemutai, L. \& Chumba, S. K. (2014). Student councils' participation in decision making in public secondary schools in Kericho West Sub- County, Kenya. International Journal of Advanced Research. 2(6), 850-858.

Cockburn, D. (2006). Mapping student involvement. Paper presented at the Sparqs Conference on student involvement at Lauder College Dunfermline.

Dowling, M. (2003) Engagement within the school community: The role of the student council and the response of school management. Unpublished Thesis, Department of Education, NUI Maynooth.

Edelstein, W. (2011). Education for democracy: Reasons and strategies. European Journal of Education, 46(1), 6-9.

Hine, G. S. (2014). Student leadership development: A functional framework. Journal of Catholic Education, 18(1). 79-110.

Kikuvi, J. M. (2004). A study of leadership training needs of prefects in public secondary schools in Machakor District, M. Ed. Dissertation. University of Nairobi.

Kinyua, A. C. (2015). Factors influencing effectiveness of student councils in public secondary schools in Kirinyaga East sub-county, Kenya, M. Ed Dissertation, University of Nairobi.

Kiruthu, F. (2011). The evolving world: A history and government course books, Nairobi: Oxford Press.

Kuranchie, A. (2016). Research made easy, Kumasi: Bookworm Publications

Kuranchie, A. (2019). The educator's guide. ( $2^{\text {nd }}$ ed.). Kumasi: Bookworm Publications.

Kyei-Badu, F. (2010). Students' perception of their participation in decision-making at Wesley College of Education in Kumasi. MPhil. Dissertation, University of Cape Coast.

Kyungu, P. M. (2009). Leadership and discipline: The role of prefect in school. Nairobi. MOE Resource Centre.

Levin, B. (2000). Putting students at the centre in education reform. Journal of Educational Change, 1(2), 155-172.

Mncube, V. (2008). Democratisation of education in South Africa. South African Journal of Education; 28, 77-90.

Mukiri, M. T. (2014). Role of student council in secondary schools' management in Mwingi Central District, Kitui County, Kenya, M. Ed. Dissertation. Kenyatta University.

Mule, M. J. (2011). Factors influencing student leaders' involvement in governance of public secondary schools in Mwala district, Kenya. M.Ed. Dissertation, University of Nairobi.

Myers, T. (2005). Developing a Culture of Student Leadership. Teacher, 155(1), 26-29.

National Youth Council of Ireland (2011). Lending a hand: A report on young people and volunteering in Ireland. Dublin: National Youth Council of Ireland.

Njogu K. (2004). Potential Leadership Training Grounds: Special Report: East African Standard. Student Leadership.

Northouse, P. G. (2004). Leadership theory and practice. ( $3^{\text {rd }}$ ed.). London: Sage Publications. 
INTERNATIONAL JOURNAL OF ACADEMIC RESEARCH IN PROGRESSIVE EDUCATION AND

DEVELOPMENT

Vol. 10, No. 1, 2021, E-ISSN: 2226-6348 @ 2021 HRMARS

O'Brien, J., \& Kohlmeier, J. (2003). Leadership: part of the civic mission of school? The Social Studies, 94 (4), 161-167.

Obiero, N. A. (2012). The Involvement of Student Leaders in the Governance of University: An Implication of Shared Leadership. M phil. Thesis, University of Oslo.

Obondo, A. (2000). Politics of Participatory Decision-Making in Campus Governance. Nairobi: University of Nairobi.

Okumbe, J. A. (2001). Human Resource Management: An Education Perspective. Nairobi, Nairobi University Press. 